\title{
Assessment of Eco-Friendly Pavement Construction and Maintenance Using Multi-Recycled RAP Mixtures
}

\author{
David Vandewalle ${ }^{1,2}$, Vítor Antunes ${ }^{3,4, *}$, José Neves ${ }^{3}[$ and Ana Cristina Freire 4 \\ 1 Department of Civil Engineering, Ghent University, St. Pieternieuwstraat 33, 9000 Ghent, Belgium; \\ djvdwall.vandewalle@ugent.be \\ 2 Department of Civil Engineering, Architecture and Georesources, Instituto Superior Técnico, Universidade \\ de Lisboa, Av. Rovisco Pais, 1049-001 Lisboa, Portugal \\ 3 Department of Civil Engineering, Architecture and Georesources, CERIS, Instituto Superior Técnico, \\ Universidade de Lisboa, Av. Rovisco Pais, 1049-001 Lisboa, Portugal; jose.manuel.neves@tecnico.ulisboa.pt \\ 4 LNEC, National Laboratory of Civil Engineering, Av. do Brasil 101, 1700-066 Lisboa, Portugal; \\ acfreire@lnec.pt \\ * Correspondence: vitorfsantunes@tecnico.ulisboa.pt
}

Received: 16 July 2020; Accepted: 12 August 2020; Published: 14 August 2020

check for updates

\begin{abstract}
The demand for more sustainable solutions has led an ever-growing number of stakeholders to being committed to pursue the principles of sustainability in pavement management. Different stakeholders have been looking for tools and methodologies to evaluate the environmental impacts of the solutions, for which the life cycle assessment (LCA) proved to be an appropriate methodology. This paper is focused on the LCA of road pavement multi-recycling based on the use of bituminous mixtures with high rates of reclaimed asphalt pavement (RAP). In order to promote the circular economy, a comparative analysis was performed on a road pavement section by taking into account different scenarios, which stem from the combination of production, construction and rehabilitation activities incorporating different RAP rates in new bituminous mixtures: $0 \%$ (as reference), $25 \%, 50 \%, 75 \%$ and $100 \%$, respectively. LCA results have been expressed in terms of four damage categories: human health, ecosystem quality, climate change and resources. Results have shown that both recycled and multi-recycled bituminous mixtures lead to substantial benefits in comparison with the solution employing virgin materials, hence embodying a sustainable approach. The benefits grow with the increase in the RAP rate with an average decrease of $19 \%, 23 \%$, $31 \%$ and $33 \%$ in all the impact categories for a $25 \%, 50 \%, 75 \%$ and $100 \%$ of RAP rate.
\end{abstract}

Keywords: LCA; road pavement management; RAP; multi-recycling; circular economy; sustainability

\section{Introduction}

The road infrastructure is one of the most important and omnipresent assets in construction engineering. In fact, roads are not only an important part of a society's transportation network, but also a public asset in overall terms. Indeed, the transport of goods and people worldwide is mainly done by road infrastructures.

Consequently, in view of the importance of these infrastructures and the need to guarantee appropriate both short and long-term behaviors of the road networks worldwide, several tonnes of bituminous mixtures are produced every year. In 2007, 1.6 trillion tonnes of bituminous mixtures were produced worldwide [1]. Around the world, pavement construction companies are required to provide end-products complying with both the high standards, defined by road authorities, and the sustainability criteria. The life cycle assessment (LCA) is a methodology intended to assess the 
environmental impacts associated with all stages of the life cycle of a solution, or product, during the manufacture, distribution, usage and after recycling or final disposal in a landfill, similarly to the operations associated with road pavement construction.

Bituminous courses have a limited usage period, due to ageing and other deterioration phenomena, and must hence be replaced after this period. Therefore, every year huge budgets are allocated to road pavement management (construction, maintenance and rehabilitation actions). During maintenance and rehabilitation actions of bituminous pavements, huge quantities of reclaimed asphalt pavement (RAP) are produced. This secondary raw material can be recycled in similar applications. RAP is defined as the removed asphalt materials containing bitumen and aggregates, which result from reconstruction and resurfacing activities, or from actions intended to obtain access to buried utilities or also from reject and surplus production [2].

Due to fairly recent developments, such as the increase in energy costs, as well as accrued environmental concerns and common sustainability awareness, there has been a shift in focus when it comes to evaluating assets that are procured and used. Governments are trying to minimize both the life cycle costs and the environmental impact, instead of simply considering the lowest cost alone when it comes to achieving added value from constructed assets [3,4].

A rising number of different stakeholders are taking account of sustainability issues in their management and business activities, namely the ones associated to the road industry. This allows stakeholders to implement in their decision-making process other key aspects that, until now, had not been seen as fundamental, such as the life cycle economic, environmental and social impacts. For this the multi-criteria decision analysis had been used. The recent guidelines issued for 2050 the construction sector presupposed by those for 2020. They continue to pursue and increase the sustainable competitiveness of the sector and deal with further challenges [5].

Pavement asset management actors have been pursuing further sustainable solutions and practices to adopt in their construction and maintenance actions [6-8]. The general approach for improving sustainability consists of reducing energy consumed, emissions generated and the amounts of virgin material used. This means implementing preventive maintenance, lowering the bituminous mixture heat and adopting other eco-friendly pavement technologies.

One of the most common methods to address these concerns and correctly quantify emissions, as well as the consumption of materials and energy, is the LCA [9-14].

This paper aims to present an attributional LCA of alternative solutions incorporating high RAP recycling rates in new bituminous mixtures. Considering the limited life period of the bituminous solutions, more than one-time RAP recycling was taken into consideration. Therefore, this paper focuses on: (1) multi-recycling solutions with high RAP incorporation rates to provide a clear understanding on how RAP and the multi-recycling of flexible pavements affect the pavement's life-cycle; (2) modelling of the recycled mixture's production phase considering the RAP's processing necessary to have greater control over the mixture's properties and performance, and consequently increase the incorporation rates. For the latter, it was assessed the impacts of each process directly related with the production of the bituminous mixture. Both analyses were performed by assessing four impact damage categories: human health, resource consumption, climate change and ecosystem quality; together with 15 impact factors. To perform such an analysis, a real road section with real implemented solutions was compared with the alternative solutions.

\section{Background}

LCA allows investigating the environmental aspects of products, services or any activity associated with them, by categorizing and measuring the contributions during the flow, since the beginning up to the final product, from a life cycle perception. The LCA method should preferably be totally inclusive, insofar as it should assess the full environmental impact and include all processes from a cradle-to-grave approach. For a pavement LCA, this means that it begins with the extraction of raw materials and ends with their landfill disposal, when a conventional linear economy is considered. 
The LCA methodology was standardized in the ISO 14040 series that divides the LCA framework into four steps [15,16]: Goal and scope definition (ISO 14040: 1997); Inventory assessment (ISO 14040: 1997); Impact assessment (ISO 14042: 2000) and Interpretation (ISO 14043: 2000).

Although the above-mentioned standards were combined in EN ISO 14040:2006 [17], the general LCA framework described in this standard still integrates the same four steps. Actually, the methodology proposed in this study follows this general framework.

When innovative materials and/or solutions are under development, the use of LCA tools allows assessing the gains or losses in terms of environmental impacts. These tools are appropriate to measure the benefits, in terms of reduction in the use of raw materials and non-renewable resources, when recycled materials are included in the adopted solutions [15,18-27].

The European Union issued some strategies to encourage the recycling and reuse of by-products and wastes. The Directive 2008/98/EC established that all EU member states should define guidelines to support the re-use of products and to prepare for re-use activities, with a view to achieve a high-quality recycling. RAP recycling in similar applications, as a secondary raw material, promotes the material circular economy that is included in the European Commission package issued in December 2015 [28]. It establishes that, in a circular economy, the value of the products is perpetuated for the maximum length of time. When a product achieves its end-of-life, it will be re-used to create further value, i.e., a cradle-to-cradle application, reducing the landfill needs and the consumption of natural resources $[3,7,29,30]$.

The ever-growing procurement for greener and more sustainable solutions has been the basis for the adoption of RAP recycling solutions in bituminous mixtures. Bituminous mixture recycling is a progress toward achieving sustainable pavement systems [10,31-39]. The paving recycled solutions provide an important contribution to the paving industry to attain a sustainable economic and environmental development. This diminishes the depletion of quality resources in landfills (e.g., bitumen and aggregates), which are finite and costly.

RAP recycling in similar applications has environmental and economic benefits $[32,40]$. The savings in the amount of necessary aggregates and binder and the consequent reduction in their transportation to the plant site leads to economic benefits. The savings in raw materials have a direct impact on the reduction in fuel emission and consumption, during the operations of extraction, processing and transportation of these materials. Furthermore, it leads to a decreased need for non-renewable resources, landfill transportation and space for the disposal of used pavement materials [7,41,42].

Since the first application of RAP in new bituminous mixtures, several studies have been developed using different RAP incorporation rates, mixing techniques and recycling agents or rejuvenators [34,37,38,43-62]. Different RAP recycling rates, varying between 0 and $100 \%$, were found in the literature for different application courses, e.g., base to surface courses. Several real applications, using in-plant and in-place recycling techniques, which presented good results, have been reported since the 1970s. It must be noted that, in these years, the knowledge about recycling techniques and appropriate plants was still underdeveloped. However, even in these conditions, similar or greater performances were obtained when recycled and traditional courses were compared [54]. Generally, those studies revealed that the in-service performance of recycled mixtures was in line with the laboratory results. No RAP treatment was applied in the cases where the recycled mixtures exhibited a worse performance than the traditional mixes with virgin materials [37,63-65]. With proper methodology and plant upgrades, the high RAP incorporation solutions eventually led to the current application to pavement construction and rehabilitation.

\section{Methodology}

\subsection{General Procedure}

This paper evaluates high RAP recycling rates in bituminous mixtures and its multi-recycling by applying an LCA to a real road section. Moreover, the RAP processing to allow higher incorporation 
percentages was modelled in the production phase to assess the additional impacts of the activities and the remaining activities (Figure 1). The focus, in this case, lies on 15 impact factors that can be broken down into four damage categories: human health (especially for construction workers and people directly involved in the production of flexible pavements), climate change, ecosystem quality and use of resources.

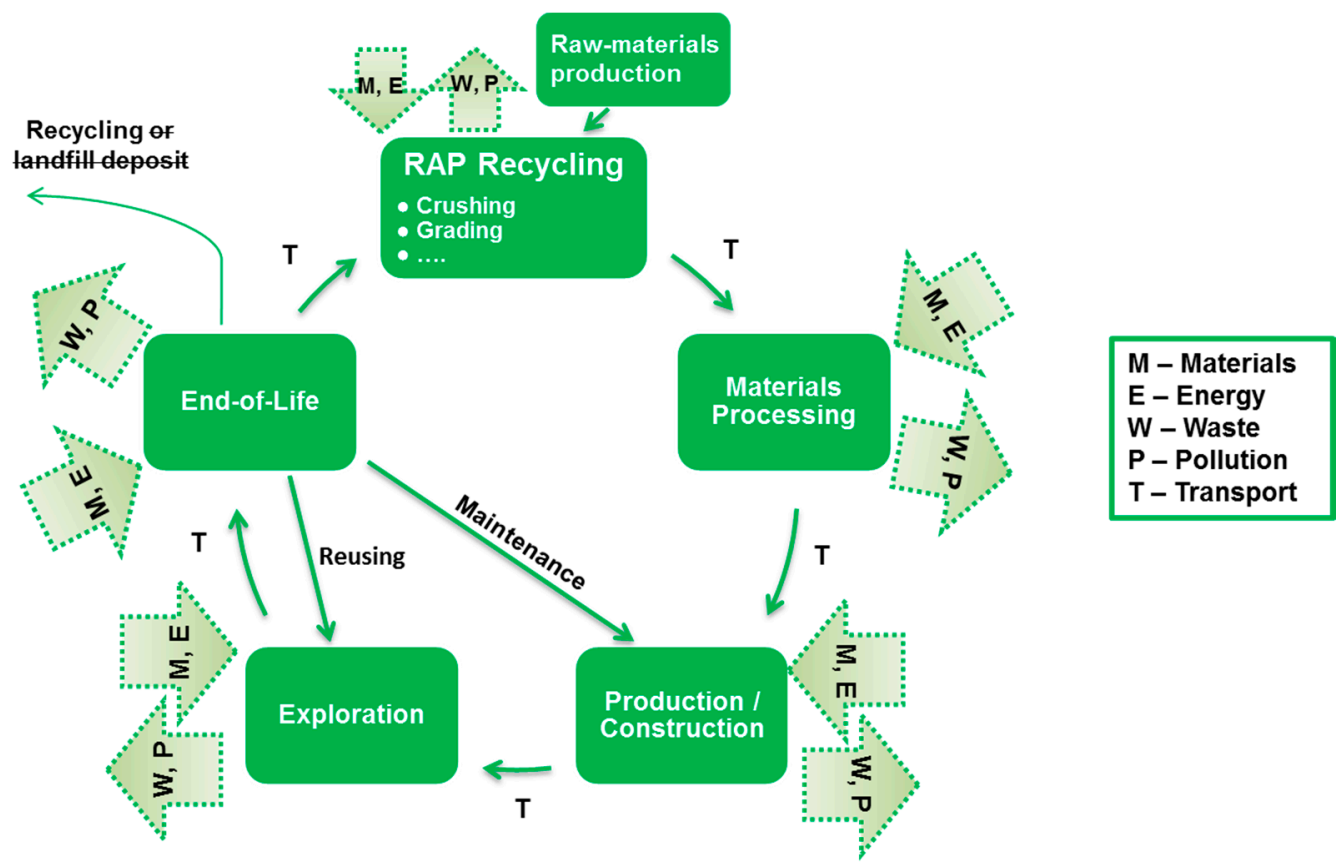

Figure 1. Phases and components of pavement life cycle assessment (LCA).

The LCA presented in this study was performed using the SimaPro software from PRé Sustainability in combination with the Ecoinvent database. This software-database combination is one of the most widely disseminated LCA tools, and provides the user with an interface, several comprehensive environmental information databases and various methods to perform the impact assessment [20]. The software provides a clear interface to perform a full LCA, comprising the four steps described in EN ISO 14040: 2006 [17]. The Ecoinvent database is the most widely used in the construction sector. The database used was the Ecoinvent 3-allocation, cut-off by classification-unit base. The underlying philosophy of the cut-off approach is that the producer does not obtain any credit for the provision of recyclable materials, but is nonetheless fully responsible for their disposal as waste [66].

\subsection{Functional Unit}

The LCA functional unit creates the basis for comparing the different structure scenarios with the same utility for an equivalent function $[12,67,68]$. In this case, it involved a pavement unit that carried the same number of vehicles per year, over the same project analysis period (PAP). This period comprised the different periods referred to by different authors and specifications $[6,9,29,67,69-73]$. The functional unit presented in this LCA was a real $1 \mathrm{~km}$-long road section of a two-lane roadway, one in each direction, with an individual width of $3.5 \mathrm{~m}$ each and a total PAP of 69 years, from 1946 to 2015. The geometric characteristics, as well as the different mixtures used for each course, are presented in Figure 2. This figure also displays the overall maintenance and rehabilitation (M\&R) strategy applied in reality by roadway concession holder (tasks, courses and application scheduling) and the 2 main structure scenarios considered in this LCA. 


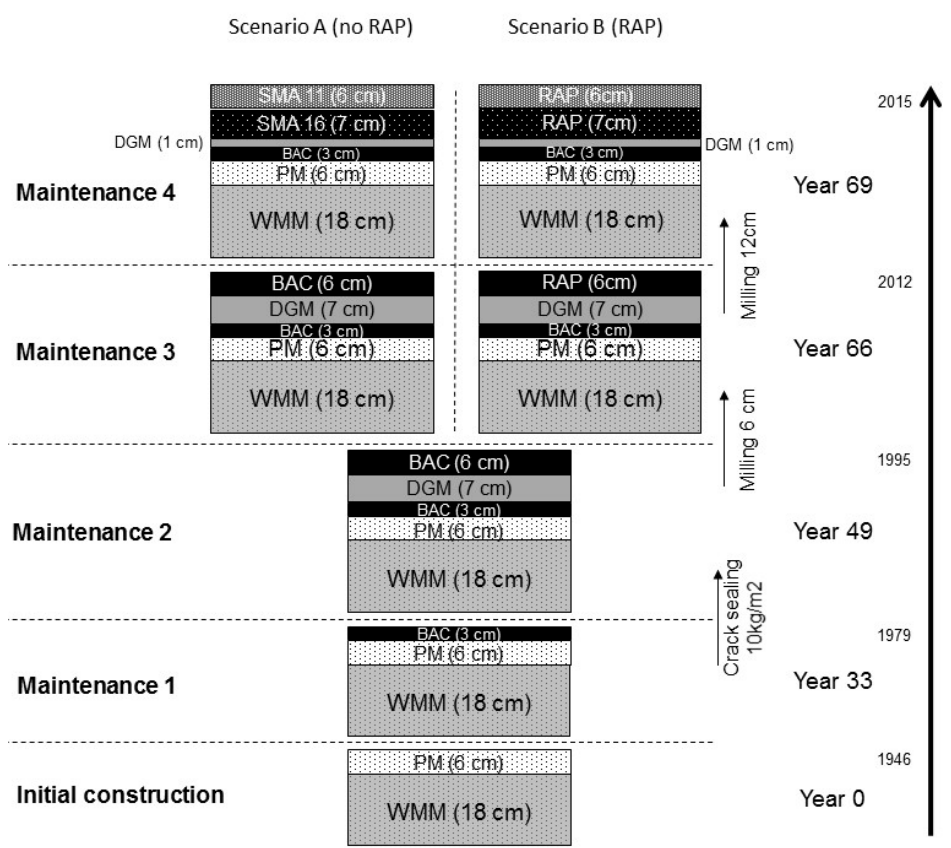

Figure 2. Flexible pavement structure and maintenance and rehabilitation strategies. WMM: wet mix macadam (hydraulic material); PM: penetration macadam; DGM: Dense-graded bituminous mixture; BAC: Bituminous asphalt concrete; SMA 16: stone mastic asphalt 16; Binder course PMB 45/80-65; SMA 11: stone mastic asphalt 11; Surface course PMB 45/80-65; RAP: Reclaimed asphalt pavement.

The first three phases of the pavement construction and maintenance history: initial construction, maintenance 1 and maintenance 2, were equal for both scenarios (A and B). Equal construction solutions and materials were also considered. Thus, these construction and maintenance actions were not taken into account in the study. For the remaining maintenance tasks, equal dates for the maintenance actions were assumed for both scenarios. However, these scenarios presented different solutions for the bituminous mixture to be applied. As such, the scenario A represents the real road section with the applied solutions and maintenance action performed by the roadway concession holder; whereas the scenario B is a proposed alternative scenario to be evaluated in the study. Scenario B considered alternative solutions using hot recycled bituminous mixtures assessed assuming the same geometry, traffic increasing and maintenance periods applied in real road section (scenario A), as presented in Figure 2. The maintenances 3 and 4, applied in scenario A and simulated in scenario B, were as follows:

- Maintenance 3 implied the milling of the bituminous dense-graded mixture (AC) of the surface course and its replacement by a new surface course. In scenario A, this course consisted of a virgin $A C$, while in scenario $B$ this course incorporated virgin $A C$, together with a certain rate of RAP that was obtained from the milling using a rejuvenator percentage.

- Maintenance 4 implied the milling of both upper courses and their replacement by a new binder and surface course, respectively. In the case of scenario A, these courses consisted of stone mastic asphalt (SMA) mixtures with virgin materials, while in the courses in scenario $B$ a certain RAP rate was incorporated together with virgin $\mathrm{AC}$ using a rejuvenator percentage.

To assess the use of RAP material in new bituminous mixtures, different incorporation rates were considered in this LCA. Scenario B was broken down into 4 sub-scenarios, hereafter referred to as "LCSx", as can be seen in Table 1. Scenario A was subsequently renamed LCS0 to simplify comparison in the remaining course of the LCA. 
Table 1. Definition of studied scenarios.

\begin{tabular}{ccc}
\hline Scenario & RAP (\%) & Reference \\
\hline Scenario A & 0 & LCS0 \\
\hline & 25 & LCS1 \\
Scenario B & 50 & LCS2 \\
& 75 & LCS3 \\
& 100 & LCS4 \\
\hline
\end{tabular}

* mass percentage.

\subsection{System Description and Boundaries}

Both base and surface courses were set as the boundaries of the LCA analysis. Due to the insufficient and outdated data regarding wet mix macadam (WMM) and penetration macadam (PM) courses, these were not considered in the LCA. Given the comparative nature of this LCA and the fact that these two courses were present throughout all scenarios, this omission had no relative impact on the LCA outcome. The following boundaries were subsequently included:

- The construction of the courses, as well as the rehabilitation and maintenance activities, were limited by the previously defined boundaries and were in conformity with the dates and course thicknesses of the real section (Scenario A).

- Raw materials extraction needs to produce the mixtures applied in those courses.

All the transportation needs as refers to the transport of raw materials from the suppliers to the bituminous plant, and from the bituminous plant to the work-site and vice-versa. Considering the RAP system boundaries, a distinction was established between the pre- and post-processing of the RAP. A 'cut-off' allocation approach, as described in [6], implied that only the post-processing of recycled material, such as RAP should be accounted for by the system. In this case, this would imply that any environmental impact, resulting from the milling and hauling of RAP, would be excluded from the system. These processes, however, were already an inherent part of the considered M\&R activities of the pavement and were, therefore, accounted for in the LCA.

\subsection{Collected Data}

Two types of data are essential for an LCA [74]:

- Primary data, which is specific for the production, processes of the product or service. This data is obtained from the goods' producers, and the operators of processes and services, as well as their associations.

- Secondary data presents generic and/or average data for the studied solution, considering the products and operations. Secondary data can be obtained from the sources of primary data, sometimes with some modifications, and from national databases, consultants and research groups.

For this study, the data was selected to be as representative of the Portuguese conditions during the PAP as possible. The sources for these data included national road authorities, active construction companies and technical experts. The data was mostly related to the inventory analysis of raw material extraction and production, fuels, construction and transportation vehicles and machines. This information was obtained primarily from the Ecoinvent database, but was modified whenever possible and appropriate to approach the Portuguese reality. The different data were combined in SimaPro to model the life cycles for the five different solutions defined as LCSx, where $\mathrm{x}$ is the number of the solution $[75,76]$. 


\section{Life Cycle Inventory}

\subsection{General Implementation}

The life cycle inventory (LCI) stage consisted of the actual data collection and modelling of the system. First, this paragraph briefly discusses both the functionality and the modelling features of SimaPro. Secondly, it addresses the data sources, the calculations that were performed to provide significant input and the modelling of the distinct phases of each LCSx in SimaPro.

\subsection{Extraction Phase}

The extraction phase of materials comprised the two sub-phases as follows: production and transport of virgin materials. To calculate the required amount of virgin aggregate and virgin binder for each course, several calculations were performed. The starting point of these calculations was the primary data, obtained from a variety of sources, in combination with the characteristics of the functional unit, the length and width of the unit of pavement and the depth of each course.

First, to determine these amounts, a fixed binder-aggregate ratio of 95-5 was determined for all mixtures, except for the SMA mixtures, which have a 93.5-6.5 ratio. This implies that, regardless of the technical specifications, the majority of mixtures contains $95 \%$ aggregate and $5 \%$ binder. Furthermore, to derive the amount of virgin aggregate and binder from the total amount of material, the RAP incorporation percentage for each specific course was determined. Table 2 shows the Ecoinvent unit processes associated with the production of virgin aggregate and binder, as well as the transport of these materials by truck.

Table 2. Material extraction processes and corresponding SimaPro unit processes.

\begin{tabular}{cc}
\hline Process Definition & SimaPro Unit Process \\
\hline Production of virgin aggregate & Gravel, crushed (RoW) | production \\
Production of virgin bituminous binder & Pitch (RoW) | petroleum refinery operation \\
Transport of aggregate and binder & Transport, freight, lorry $>$ 32 metric tonne, EURO4 (GLO) \\
\hline
\end{tabular}

The second sub-phase of the extraction of materials involved the transport of virgin material to the bituminous mixing plant. The selected unit process for transport by truck in SimaPro, "Transport, freight, lorry > 32 metric tonnes, EURO4 (GLO), has a default unit of tonne-kilometre (tkm)". To define this amount for each course, the total mass of transported material and the distance between the production site and the mixing plant were calculated. A distance of $100 \mathrm{~km}$ and $150 \mathrm{~km}$ was considered from the quarry to the mixing plant and from the binder supplier to the mixing plant, respectively.

\subsection{Production Phase}

The mixture production phase addresses the environmental impacts related to the production of the different mixtures considered in the system. It was assumed that all the mixtures were produced at a conventional heavy fuel oil (HFO) fired batch mix plant. To account for variations in composition, mixing temperature, moisture content of aggregates and initial temperature of raw materials, of the several types of mixtures, the thermal energy (TE), required to produce the different bituminous mixtures, was determined according to Equation (1) [67].

$$
T E=\left[\begin{array}{c}
\sum_{i=0}^{M} m_{i} \times C_{i} \times\left(t_{\text {mix }}-t_{0}\right)+m_{\text {bit }} \times C_{\text {bit }} \times\left(t_{\text {mix }}-t_{0}\right)+\sum_{i=0}^{M} m_{i} \times W_{i} \times C_{w} \times\left(100-t_{0}\right) \\
+L_{v} \times \sum_{i=0}^{M} m_{i} \times W_{i}+\sum_{i=0}^{M} m_{i} \times W_{i} \times C_{\text {vap }} \times\left(t_{\text {mix }}-100\right)
\end{array}\right] \times(1+C L)
$$

where,

- $\quad T E$ is the thermal energy (MJ/tonmixture) necessary to produce one ton of bituminous mixture; 
- $m_{i}$ is the mass of aggregates of fraction $i$;

- $C_{i}$ is the specific heat capacity coefficient of aggregate fraction $i$;

- $\quad M$ is the total number of aggregate fractions;

- $t_{m i x}$ is the mixing temperature of a bituminous mixture;

- $t_{0}$ is the ambient temperature;

- $m_{b i t}$ is the mass of bitumen;

- $C_{b i t}$ is the specific heat capacity coefficient of bitumen;

- $W_{i}$ is the water content of aggregates of fraction $i$;

- $C_{w}$ is the specific heat capacity coefficient of water;

- $L_{v}$ is the latent heat required to evaporate water;

- $C_{\text {vap }}$ is the specific heat capacity coefficient of water vapour;

- $C L$ is the casing losses factor.

The casing losses $(C L)$ is defined as the thermal energy that is lost by heating plant iron, instead of being used to heat the mixture components [21]. This factor was considered the same for all mixtures presented in this study, in accordance with the findings presented by Santos et al. (2018).

The different parameter values were based on literature and on average values in real practice $[21,67,77]$.

Table 3 shows the values of the parameters used to calculate the thermal energy. For the mixtures, the standardized values were applied according to EN 12697-35 [77].

Table 3. Parameter values of thermal energy.

\begin{tabular}{clcc}
\hline Parameter & Definition & Value & Unit \\
\hline$t_{0}$ & Ambient temperature & 15 & ${ }^{\circ} \mathrm{C}$ \\
$C_{a g g}$ & Specific heat of virgin aggregates & 0.74 & $\mathrm{~kJ} / \mathrm{kg} /{ }^{\circ} \mathrm{C}$ \\
$W_{a g g}$ & Water content of aggregates & 3 & $\% / \mathrm{m}$ agg \\
$C_{R A P}$ & Specific heat of RAP & 0.74 & $\mathrm{~kJ} / \mathrm{kg} /{ }^{\circ} \mathrm{C}$ \\
$C_{w}$ & Specific heat of water at $15^{\circ} \mathrm{C}$ & 4.1855 & $\mathrm{~kJ} / \mathrm{kg} /{ }^{\circ} \mathrm{C}$ \\
$L_{v}$ & Latent heat of vaporization of water & 2256 & $\mathrm{~kJ} / \mathrm{kg}$ \\
$C_{\text {vap }}$ & Specific heat of water vapour & 1.83 & $\mathrm{~kJ} / \mathrm{kg}$ \\
$C_{b i t}$ & Specific heat of bitumen & 2.093 & $\mathrm{~kJ} / \mathrm{kg} /{ }^{\circ} \mathrm{C}$ \\
$C L$ & General casing losses factor & 27 & $\%$ \\
\hline
\end{tabular}

The actual environmental impact, resulting from the production of the bituminous mixtures, was modelled by the SimaPro unit process "heat production, heavy fuel oil, at industrial furnace $1 \mathrm{MW}$ | heat, district or industrial, other than natural gas | cut-off, $U$ " from the Ecoinvent database.

In addition to the environmental damage, resulting from the heating of the mixtures, the mixture production phase of courses incorporating RAP mixtures, also partly accounted for the impact of RAP processing. The RAP processing sub-phase was divided into pre-processing and post-processing. The pre-processing of RAP was therefore attributed to the construction and M\&R phases, while the post-processing was attributed to the mixture production phase. The post-processing of RAP consisted of four activities (crushing, stacking, conveying and screening), and was considered to have a combined capacity of 184 tonnes per hour [6].

To account for the environmental impact of RAP production in SimaPro, the four main RAP production activities, mentioned above (crushing, stacking, conveying and screening), were modelled in SimaPro by different unit processes, as Table 4 shows. As this unit process is generally expressed in hours (hr), the total amount of hours required for producing each course was thus used as input for both activities in SimaPro. 
Table 4. Reclaimed asphalt pavement (RAP) processing SimaPro unit processes.

\begin{tabular}{cc}
\hline Process Definition & SimaPro Unit Process \\
\hline Crushing of RAP by a crushing unit & Rock crushing $\{$ RER $\} \mid$ processing $\mid$ Cut-off, U \\
Stacking of RAP by a wheel loader & Excavation, skid-steer loader $\{$ RER $\} \mid$ processing $\mid$ Cut-off, $\mathrm{U}$ \\
Conveying of RAP on a conveyor belt & Machine operation, diesel, $\geq 74.57 \mathrm{~kW}$, high load factor $\{\mathrm{GLO}\}$ \\
Screening by a mobile screener & Machine operation, diesel, $\geq 74.57 \mathrm{~kW}$, high load factor $\{\mathrm{GLO}\}$ \\
\hline
\end{tabular}

\subsection{Construction and MER Phases}

The construction and M\&R phases have considerable environmental impacts on the system that need to be assessed. These impacts namely result from the machine operations involved in the construction of the courses and from the transportation of bituminous mixtures and milled material. The data concerning the activities and machine efficiencies were based on the literature review and on consultations to contractors and road experts.

Following the methodology used by other authors [67], machine operations were modelled in SimaPro using two different unit processes from the database, depending on the power of the machinery used. To describe the light machine operations, the SimaPro unit process 'Machine operation, diesel, $\geq 18.64 \mathrm{~kW}$ and $<74.57 \mathrm{~kW}$, high load factor' was used. The heavy machine operations were modelled by the unit process 'Machine operation, diesel, $\geq 74.57 \mathrm{~kW}$, high load factor'. For the transportation by truck, the 'Transport, freight, lorry > 32 metric tonnes, EURO4 | cut-off, U' was adopted.

\subsection{Work-Zone Traffic Management and Use Phases}

The work-zone traffic management phase accounts for the differential fuel cost and emissions released by on-road vehicles, due to congestions generated during $M \& R$ actions, in comparison to those generated during normal road operation [67]. Considering the nature of the analysis and the fact of the study evaluating a real section of road, due to the lack of realistic data, as refers to traffic management during maintenance phases, the environmental impacts of this phase were not included.

The use phase takes account of the environmental impacts, which result from the interaction of the pavement with the vehicles, on the environment and humans throughout its PAP [67]. Other factors have been considered during the usage phase of the pavement, namely: pavement-vehicle interaction, traffic flow, leachate, carbonization and lighting [67].

In this study, however, the usage phase was not taken into account, although the contribution of this phase to the overall environmental impact of the pavement life cycle is potentially significant (or even dominant) [78]. Again, the reason for this omission lies on the lack of well-documented information regarding the case-study. However, such omission did not have significant impacts, due to the comparative basis of the analysis performed.

\subsection{End-of-Life Phase}

The end-of-life (EOL) phase of a pavement includes the destination of the pavement after its PAP. There are two main possible destinations for a given pavement: (1) remaining in place, or, (2) removal [67]. In this study, the pavement was assumed to remain in place and to undergo maintenance 4. All environmental impacts of this phase were therefore considered in the extraction of materials, in the mixture production, in construction, and in $M \& R$ phase.

\section{Results and Discussion}

\subsection{Life Cycle Impact Assessment}

The third step of the LCA, the life cycle impact assessment (LCIA), addresses the relationship between the inventory and the exterior; what kind of effect the system has on humans and the environment. It consisted of the following steps: classification, characterization and optional normalization, grouping, and weighting [17]. The midpoint impact category and endpoint 
normalization results were calculated by applying the life cycle impact method IMPACT 2002+. IMPACT 2002+ is a combination of four methods: IMPACT 2002 [22], Eco-indicator 99 [79], CML [80] and IPCC [23].

\subsection{LCA Global Results}

To evaluate the high RAP incorporation rates, and more specifically the multi-recycling rehabilitation, five rehabilitation scenarios for the functional unit were considered, which were referred to as LCS0, LCS1, LCS2, LCS3 and LCS4 (Table 5). Classification is the first step of the LCIA, where each elementary flow is assigned to a certain impact category, in consonance with the substances' potential for this category. In the second step (characterization), the individual emissions from the elementary flows that contribute to a single impact category are summed up. Firstly, however, the emissions are converted into indicators, using factors calculated by the IMPACT 2002+ model, in order to account for their relative contribution to a certain impact category. Table 5 shows the total results for each scenario.

Table 5. Characterization results for each scenario.

\begin{tabular}{|c|c|c|c|c|c|c|}
\hline Impact Factor & Unit & LCS0 & LCS1 & LCS2 & LCS3 & LCS4 \\
\hline Carcinogens & $\mathrm{kg} \mathrm{C}_{2} \mathrm{H}_{3} \mathrm{Cl}$ eq & $4.93 \times 10^{3}$ & $3.99 \times 10^{3}$ & $3.66 \times 10^{3}$ & $3.33 \times 10^{3}$ & $3.13 \times 10^{3}$ \\
\hline Non-carcinogens & $\mathrm{kgC}_{2} \mathrm{H}_{3} \mathrm{Cleq}$ & $6.61 \times 10^{3}$ & $5.39 \times 10^{3}$ & $4.83 \times 10^{3}$ & $4.26 \times 10^{3}$ & $3.89 \times 10^{3}$ \\
\hline Respiratory inorganics & kg PM2.5 eq & $5.68 \times 10^{2}$ & $4.65 \times 10^{2}$ & $4.24 \times 10^{2}$ & $3.82 \times 10^{2}$ & $3.57 \times 10^{2}$ \\
\hline Ionizing radiation & $\mathrm{Bq} \mathrm{C}^{14} \mathrm{eq}$ & $1.13 \times 10^{7}$ & $8.46 \times 10^{6}$ & $7.61 \times 10^{6}$ & $6.76 \times 10^{6}$ & $6.47 \times 10^{6}$ \\
\hline Ozone layer depletion & $\mathrm{kg} \mathrm{CFC}^{11} \mathrm{eq}$ & $2.90 \times 10^{-1}$ & $2.15 \times 10^{-1}$ & $1.93 \times 10^{-1}$ & $1.72 \times 10^{-1}$ & $1.66 \times 10^{-1}$ \\
\hline Respiratory organics & $\mathrm{kg} \mathrm{C}_{2} \mathrm{H}_{4} \mathrm{eq}$ & $3.34 \times 10^{2}$ & $2.56 \times 10^{2}$ & $2.30 \times 10^{2}$ & $2.04 \times 10^{2}$ & $1.94 \times 10^{2}$ \\
\hline Aquatic ecotoxicity & kg TEG water & $6.37 \times 10^{7}$ & $4.85 \times 10^{7}$ & $4.35 \times 10^{7}$ & $3.87 \times 10^{7}$ & $3.65 \times 10^{7}$ \\
\hline Terrestrial ecotoxicity & kg TEG soil & $2.05 \times 10^{7}$ & $1.65 \times 10^{7}$ & $1.49 \times 10^{7}$ & $1.32 \times 10^{7}$ & $1.21 \times 10^{7}$ \\
\hline Terrestrial acid/nutri & $\mathrm{kg} \mathrm{SO}_{2} \mathrm{eq}$ & $1.03 \times 10^{4}$ & $8.43 \times 10^{3}$ & $7.74 \times 10^{3}$ & $7.02 \times 10^{3}$ & $6.58 \times 10^{3}$ \\
\hline Land occupation & $\mathrm{m}^{2}$ org.arable & $1.02 \times 10^{4}$ & $8.87 \times 10^{3}$ & $7.81 \times 10^{3}$ & $6.74 \times 10^{3}$ & $5.80 \times 10^{3}$ \\
\hline Aquatic acidification & $\mathrm{kg} \mathrm{SO}_{2} \mathrm{eq}$ & $3.50 \times 10^{3}$ & $2.82 \times 10^{3}$ & $2.61 \times 10^{3}$ & $2.40 \times 10^{3}$ & $2.29 \times 10^{3}$ \\
\hline Aquatic eutrophication & $\mathrm{kg} \mathrm{PPO}_{4} \mathrm{P}_{\mathrm{lim}}$ & $1.35 \times 10^{2}$ & $1.02 \times 10^{2}$ & $9.12 \times 10^{1}$ & $8.07 \times 10^{1}$ & $7.64 \times 10^{1}$ \\
\hline Global warming & $\mathrm{kgCO}_{2} \mathrm{eq}$ & $4.58 \times 10^{5}$ & $3.84 \times 10^{5}$ & $3.58 \times 10^{5}$ & $3.32 \times 10^{5}$ & $3.15 \times 10^{5}$ \\
\hline Non-renewable energy & MJ primary & $2.48 \times 10^{7}$ & $1.83 \times 10^{7}$ & $1.65 \times 10^{7}$ & $1.47 \times 10^{7}$ & $1.41 \times 10^{7}$ \\
\hline Mineral extraction & MJ surplus & $6.21 \times 10^{3}$ & $5.24 \times 10^{3}$ & $4.59 \times 10^{3}$ & $3.93 \times 10^{3}$ & $3.36 \times 10^{3}$ \\
\hline
\end{tabular}

Figure 3 shows the relative decrease in the characterization indicator for each scenario compared to the baseline scenario LCS0. The total average decrease for LCS1, LCS2, LCS3 and LCS4, was 20\%, 28\%, $36 \%$ and $40 \%$, respectively. As can be concluded from this figure, the use of RAP and multi-recycling led to a considerable decrease in the environmental impact across all characterization factors. Moreover, this decrease was proportionate to the rate of RAP considered in the scenario; all indicators decreased as the rate of RAP increased. For the LCS4 scenario, the biggest decrease can be observed in the mineral extraction category $(46 \%)$, while the global warming category displays the smallest decrease $(31 \%)$.

The second part of the LCIA consisted of a damage assessment. According to ISO standards, this step is optional for an LCIA and is strongly similar to the characterization one. In the damage assessment, however, the categories were defined from an endpoint approach, in contrast to the midpoint approach used in the characterization step. Each damage category was thus compiled from several impact categories. The damage categories provided by the IMPACT 2002+ method, together with their units, are presented in Table 6 . This table also includes the different impact categories assigned to each damage category. 


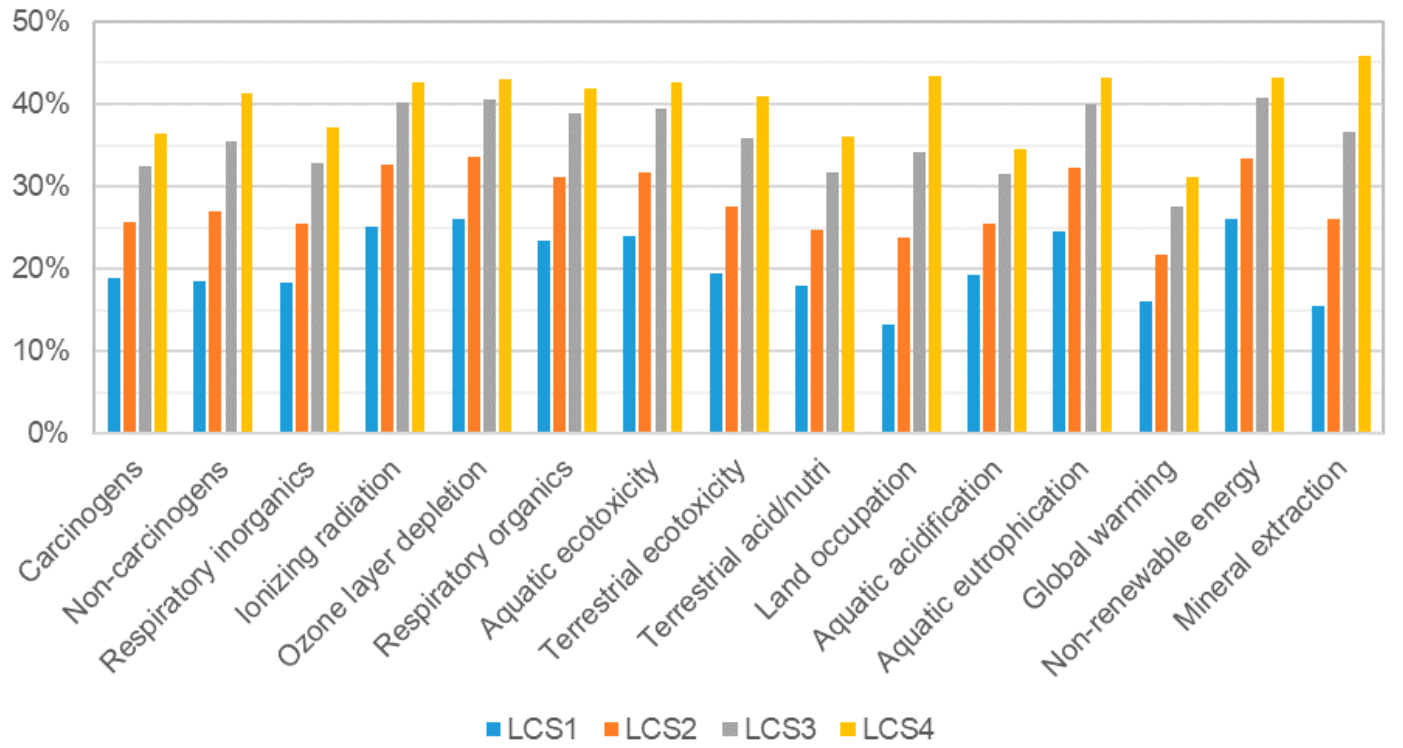

Figure 3. Characterization factors.

Table 6. Damage category definition [81].

\begin{tabular}{|c|c|c|c|}
\hline Impact Category & Damage Category & Unit & Unit Definition \\
\hline $\begin{array}{l}\text { Carcinogens } \\
\text { Non-carcinogens } \\
\text { Respiratory inorganics } \\
\text { Respiratory organics } \\
\text { Ionizing radiation } \\
\text { Ozone layer depletion }\end{array}$ & Human health & DALY & $\begin{array}{l}\text { Disability-adjusted life years: characterizes the } \\
\text { disease severity, accounting for both mortality } \\
\text { (years of life lost due to premature death) and } \\
\text { morbidity (the time of life with lower quality } \\
\text { due to an illness, e.g., at the hospital) }\end{array}$ \\
\hline $\begin{array}{l}\text { Aquatic ecotoxicity } \\
\text { Terrestrial ecotoxicity } \\
\text { Terrestrial acid/nutri } \\
\text { Land occupation } \\
\text { Aquatic acidification } \\
\text { Aquatic eutrophication }\end{array}$ & Ecosystem quality & $\mathrm{PDF} \times \mathrm{m}_{2} \times \mathrm{yr}$ & $\begin{array}{c}\text { The Potentially Disappeared Fraction of species } \\
\text { over a certain amount of } \mathrm{m}^{2} \text { during a certain } \\
\text { amount of year. }\end{array}$ \\
\hline Global warming & Climate change & $\mathrm{kg} \mathrm{CO}_{2}$ eq & $\mathrm{kg} \mathrm{CO}_{2}$ equivalents into air \\
\hline $\begin{array}{l}\text { Non-renewable energy } \\
\text { Mineral extraction }\end{array}$ & Resources & MJ primary & MJ primary non-renewable \\
\hline
\end{tabular}

Table 7 shows the total damage assessment results for each scenario. As can be expected from the characterization results, a similar decrease in impact can be observed in all damage categories for scenarios comprising RAP. Furthermore, as Figure 4 shows, this decrease is again proportional to the percentage of RAP included in the mixtures. The biggest damage category decrease was observed for resources (43\% for LCS4), and the smallest for climate change (31\% for LCS4).

Table 7. Total damage assessment results.

\begin{tabular}{ccccccc}
\hline Damage Category & Unit & LCS0 & LCS1 & LCS2 & LCS3 & LCS4 \\
\hline Human Health & DALY & 0.434 & 0.354 & 0.323 & 0.291 & 0.271 \\
Ecosystem quality & PDF $\times \mathrm{m}^{2} \times \mathrm{yr}$ & $1.88 \times 10^{5}$ & $1.52 \times 10^{5}$ & $1.36 \times 10^{5}$ & $1.21 \times 10^{5}$ & $1.11 \times 10^{5}$ \\
Climate change & $\mathrm{kg} \mathrm{CO} 2$ eq & $4.58 \times 10^{5}$ & $3.84 \times 10^{5}$ & $3.58 \times 10^{5}$ & $3.32 \times 10^{5}$ & $3.15 \times 10^{5}$ \\
Resources & MJ primary & $2.48 \times 10^{7}$ & $1.84 \times 10^{7}$ & $1.65 \times 10^{7}$ & $1.47 \times 10^{7}$ & $1.41 \times 10^{7}$ \\
\hline
\end{tabular}




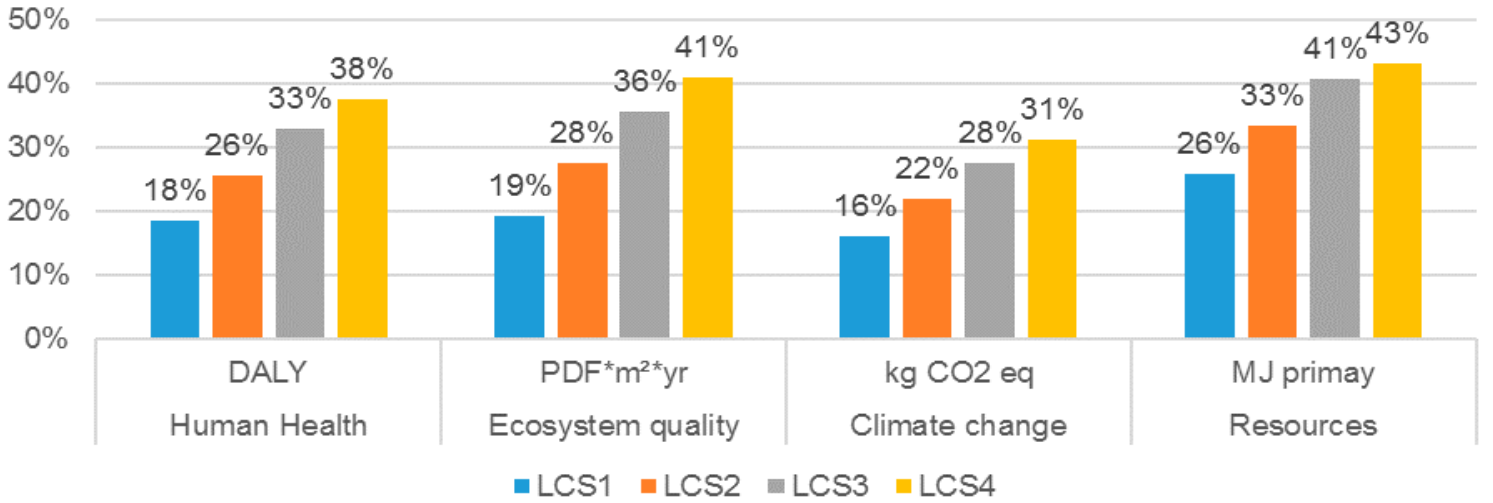

Figure 4. Relative damage category indicator compared to the baseline scenario.

The third step, normalization, was also optional according to the ISO standards. Nonetheless, it can provide valuable insight about the extent of an impact category result with a specific reference. To normalize the damage factors, each impact per unit of emission was divided by the total impact of all substances of the specific category for which characterization factors exist, per person per year (for Europe) [81]. These numbers are ratios and normalization, and therefore, resolve the mismatch of units (see Table 8).

Table 8. Total normalization results per scenario.

\begin{tabular}{cccccc}
\hline Damage Category & LCS0 & LCS1 & LCS2 & LCS3 & LCS4 \\
\hline Human Health & 61.1 & 50 & 45.6 & 41.1 & 38.3 \\
Ecosystem quality & 13.7 & 11.1 & 9.95 & 8.82 & 8.1 \\
Climate change & 46.2 & 38.8 & 36.2 & 33.5 & 31.9 \\
Resources & 163 & 121 & 109 & 96.7 & 92.8 \\
\hline
\end{tabular}

The normalization results provided a similar output to the damage assessment. Figure 5 shows the relative decrease in the normalization factor for each scenario, compared to the baseline scenario. The normalization results show great resemblance with the damage assessment outcome; the indicators of each category decrease as the RAP rate increases. For LCS4, the biggest difference was again observed in the resources category (43\%) and the smallest in the climate change category $(31 \%)$.

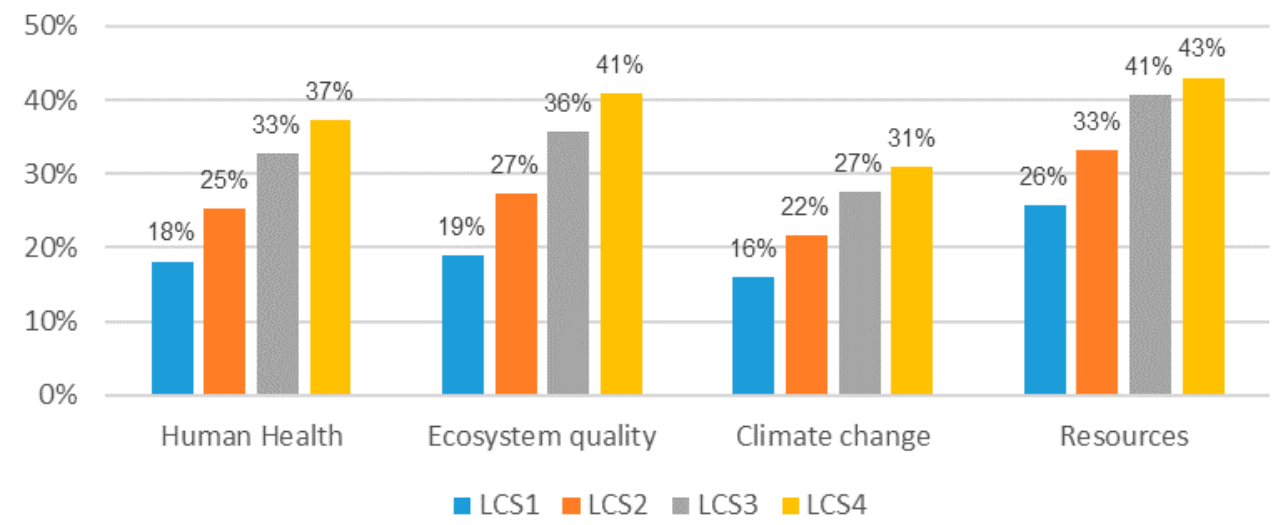

Figure 5. Normalization factor differences between LCS0 and LCS1, LCS2, LCS3 and LCS4.

A linear correlation between the RAP incorporation rate and the environmental impact can be observed. This seemed to indicate that, theoretically, when constructing or maintaining flexible pavement courses, the solutions with high RAP recycling rates should be taken into consideration. 
The results from these three steps can be explained by the following aspects: (i) replacing virgin material for RAP resulted in an obvious reduction in virgin aggregate and binder production; (ii) the contribution of RAP production process were insignificant when compared with the aggregate and binder production process; (iii) multi-recycling, or in this case study, the reuse of RAP during the 4th maintenance resulted in a second reduction in virgin materials, in comparison with the baseline scenario; (iv) due to the reduction in virgin material, there was also a reduction in virgin material transport and, hence, in the overall transport impact; (v) the SMA mixtures considered, in the baseline scenario, had a higher mixing temperature than the corresponding RAP mixtures in the alternative scenarios, thus leading to a reduction in mixture production emissions and energy.

\subsection{Assessment of RAP's Impacts on Mixture Production}

This section only evaluates the impacts of the phases directly related with the mixture production, since RAP recycling has only direct impacts in terms of raw materials needs, RAP treatments, and additional transport distance. The following topics are intended to show the impacts of the use of this material on the overall process associated with the production of mixtures.

The LCA results from the five scenarios considered in this paper were divided by the following life cycle phases: virgin material extraction (consisting of virgin aggregate production and virgin binder production), mixture production, RAP production and transport. This makes it possible to assess the contribution of each phase to the overall environmental impact of the life cycle of each scenario; the characterization results for each category being divided by each life cycle phase. These contribution results for LCS0, LCS1, LCS2, LCS3 and LCS4 are shown in Figures 6-10, respectively.

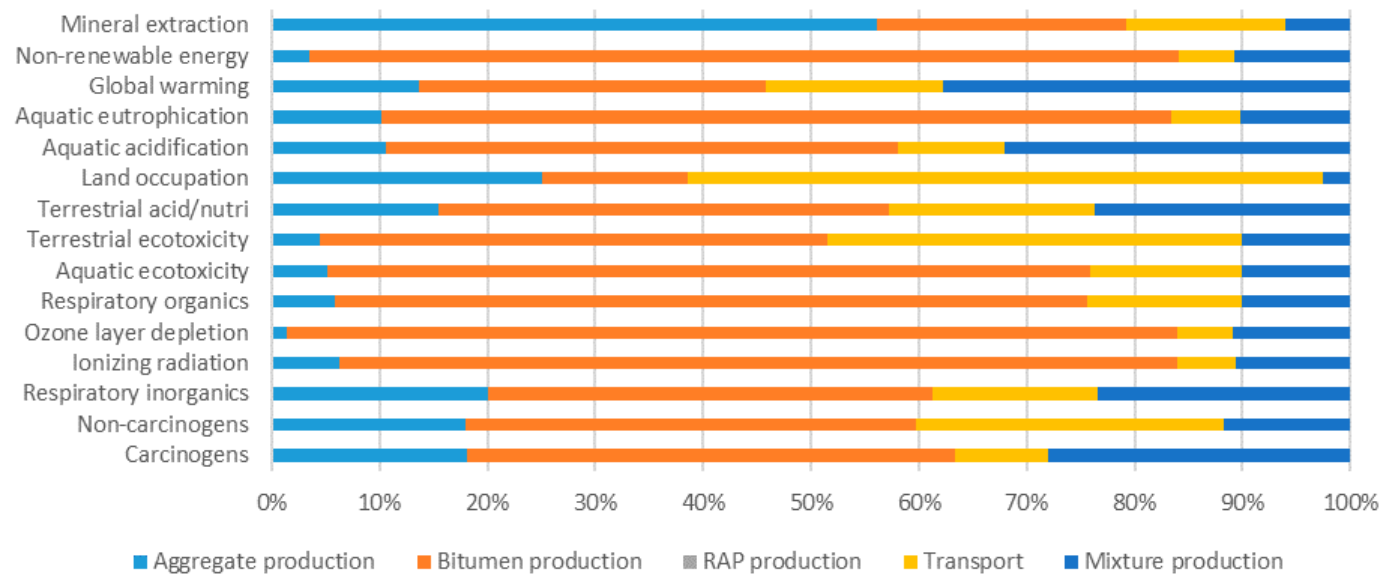

Figure 6. Life cycle phase contribution LCSO.

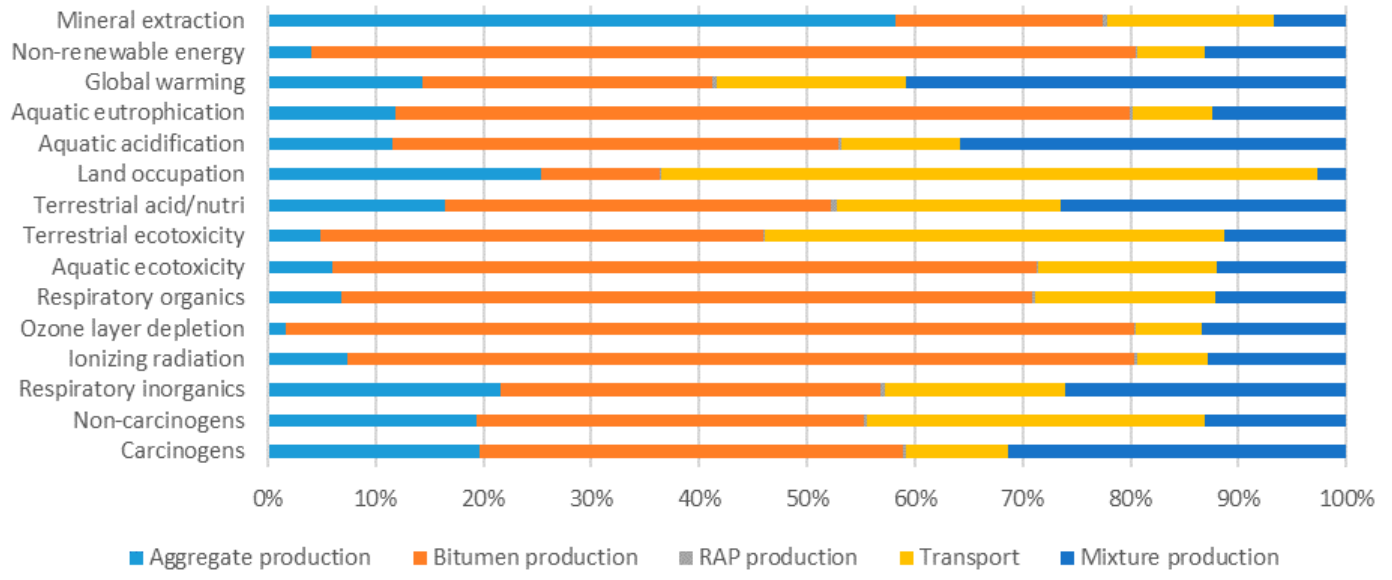

Figure 7. Life cycle phase contribution LCS1. 


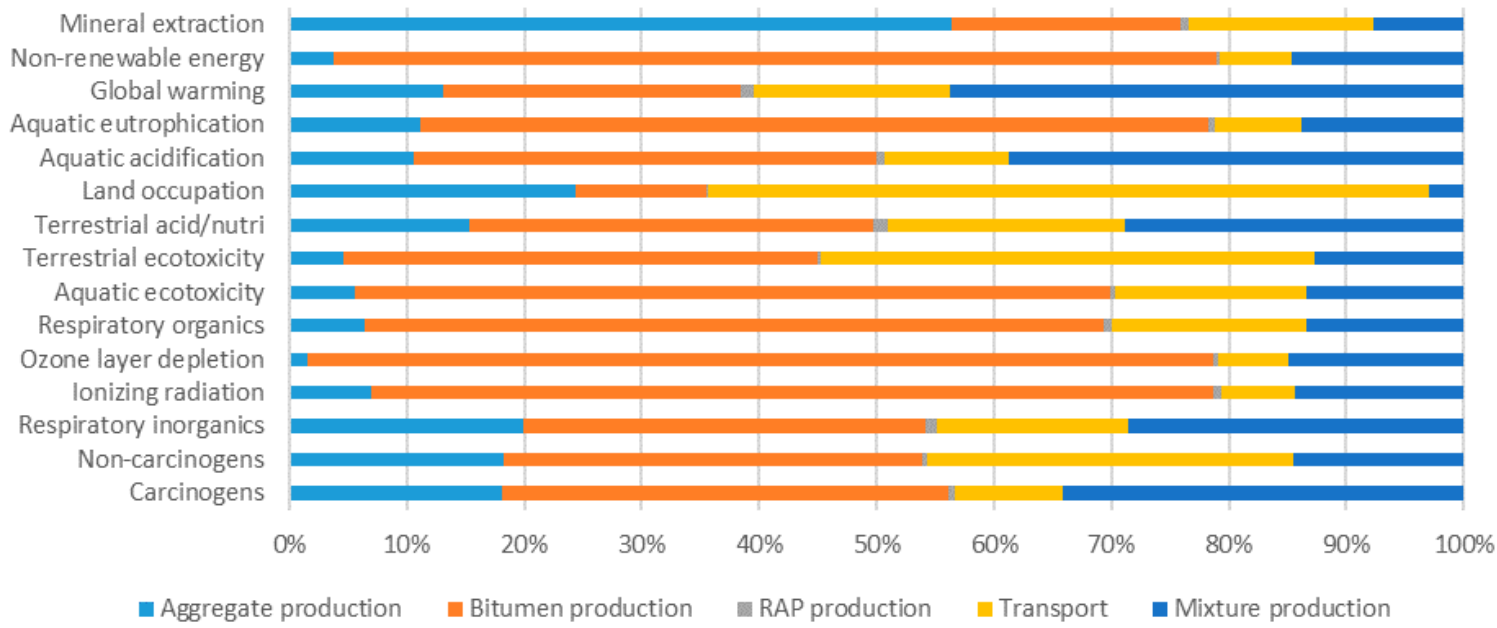

Figure 8. Life cycle phase contribution LCS2.

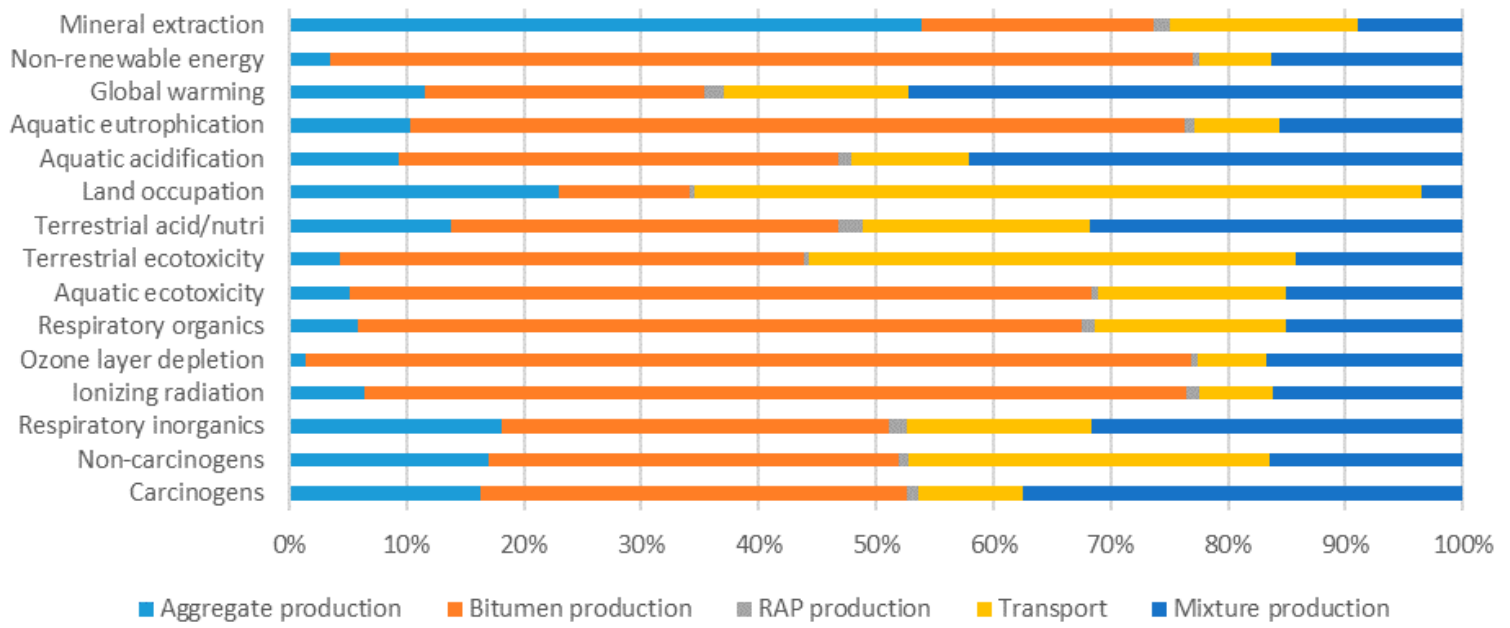

Figure 9. Life cycle phase contribution LCS3.

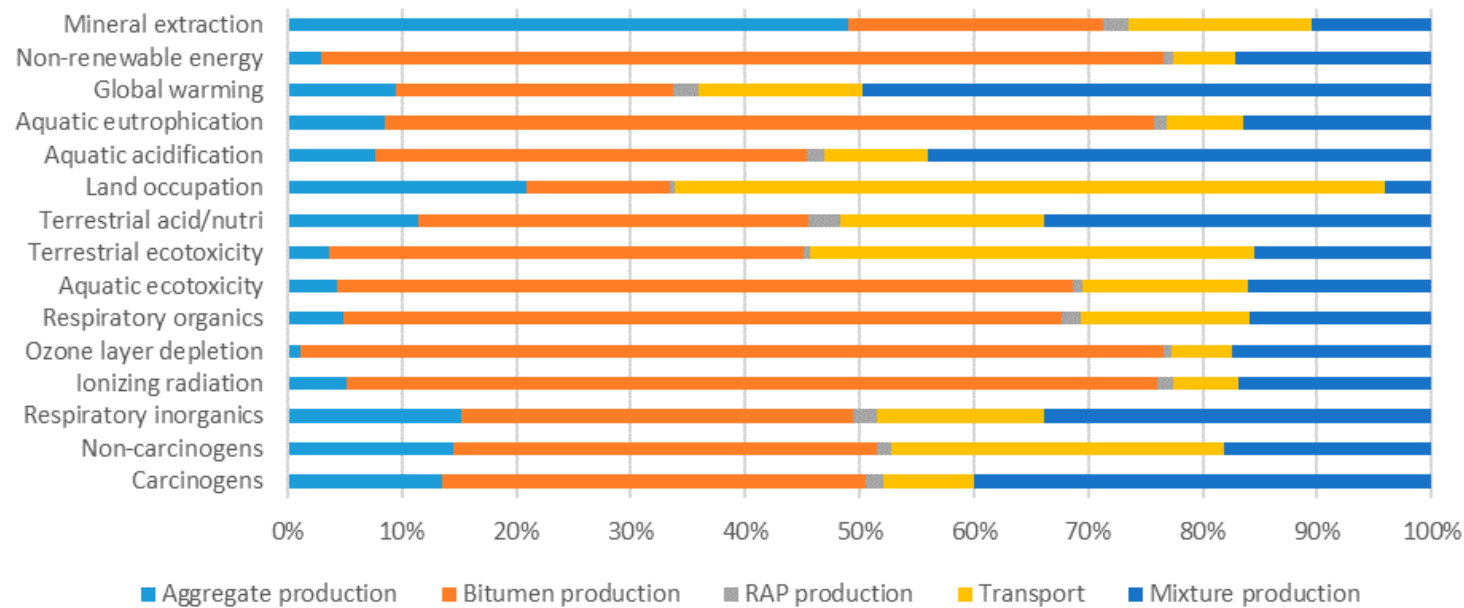

Figure 10. Life cycle phase contribution LCS4.

From these figures, it can be concluded that the production of virgin bitumen accounts for the biggest environmental impact. It has the biggest contribution to 12,11,11,9 and 10 impact categories for LCS0, LCS1, LCS2, LCS3 and LCS4, respectively. This result was in line with the results obtained in other studies $[11,78,82-84]$. Transport and mixture production had the biggest contribution to 
only one, two or three categories, depending on the scenario. The production of virgin aggregate accounted for the biggest contribution to only one impact category, mineral extraction, but across all scenarios. The environmental impact of RAP production, even in LCS4, never contributed the most to any impact category.

For each rehabilitation scenario, the relative influence of the different life cycle phases was assessed in terms of the different damage categories presented in LCA global results. This provides a more comprehensible and intuitive approach to the relative contribution of each life cycle phase to the overall environmental impact; the mentioned results for each impact category are again combined into damage factors. The results obtained for each damage category are presented in Figures 11-14.

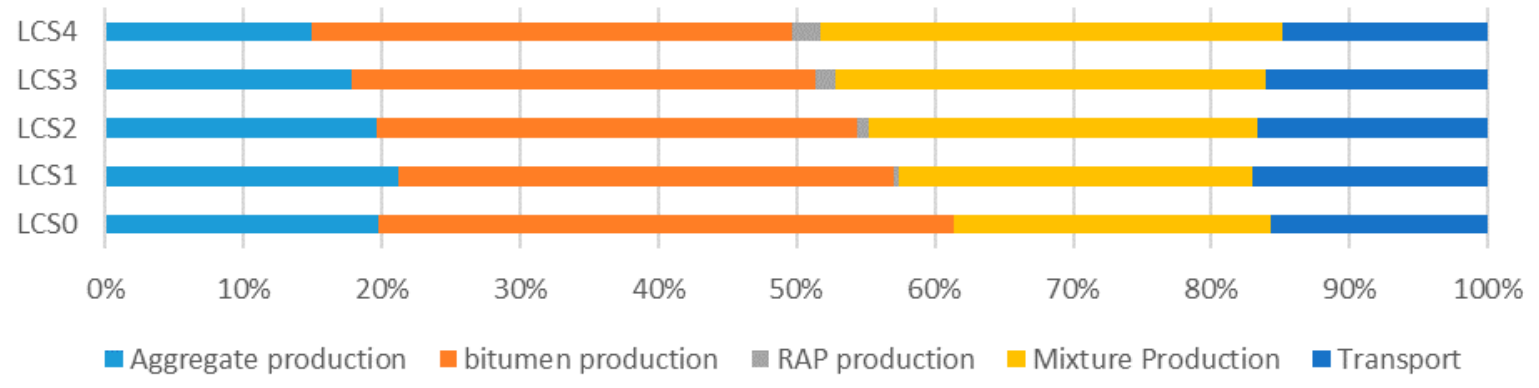

Figure 11. Relative life cycle phase contribution to the human health damage category.

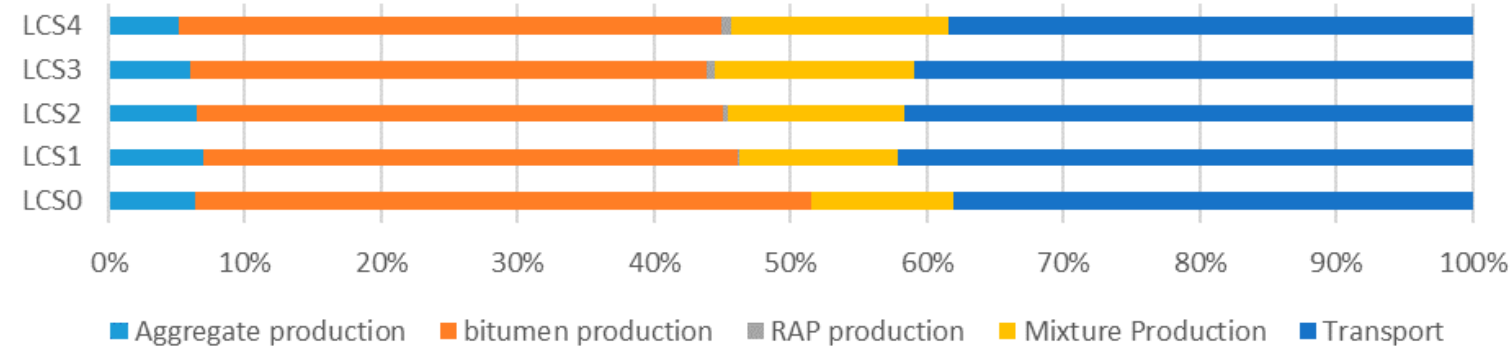

Figure 12. Relative life cycle phase contribution to the ecosystem quality damage category.

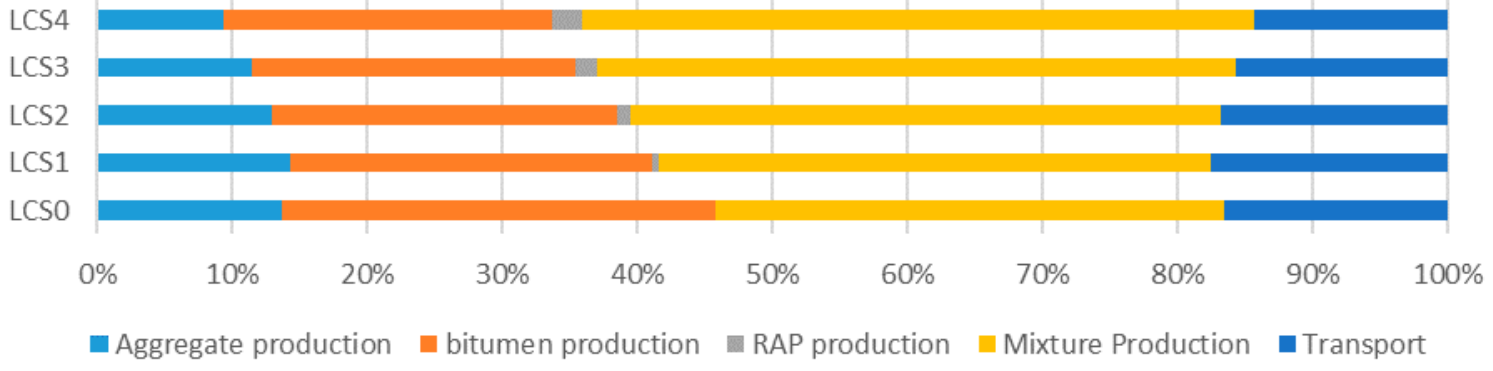

Figure 13. Relative life cycle phase contribution to the climate change damage category.

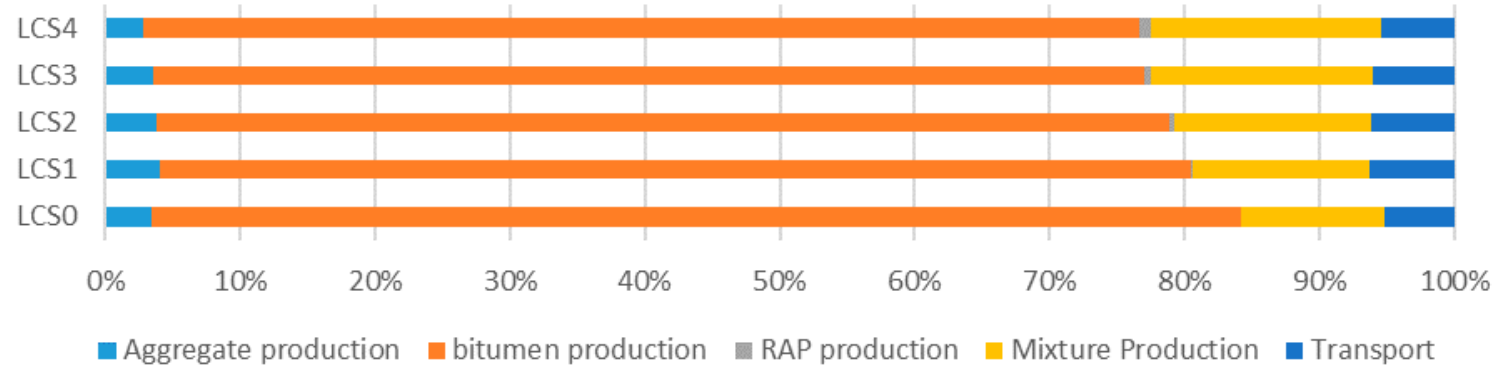

Figure 14. Relative life cycle phase contribution to the resource damage category. 
Similar conclusions can be drawn from these figures in comparison with the ones showing the contribution to all impact categories. The contribution of RAP production is insignificant for all damage categories, across all scenarios. Even the relative contribution of $2 \%$ in LCS4 $(100 \%$ of RAP incorporation) to human health, the largest impact observed, is still very small. On average, the production of bitumen delivers the greatest contribution across all damage categories except for climate change, in which the mixture production has the biggest impact. For the resource damage category, in particular, the contribution is almost $80 \%$ in the LCSO.

\section{Conclusions}

The main purpose of this paper was to evaluate the impact of high RAP incorporation and multi-recycling of bituminous mixtures in flexible pavement management. Such an impact was assessed from an environmental perspective by performing an LCA. The functional unit of this case study consisted of a flexible pavement of a road section with 1-km length and $7 \mathrm{~m}$ width, throughout a 69-year performance analysis period. The case study compared five maintenance and rehabilitation scenarios, referred to as 'LCSx', for this section, each with a different RAP incorporation rate in the bituminous mixtures: $0 \%, 25 \%, 50 \%, 75 \%$ and $100 \%$, respectively.

The case study LCA findings were the subject of the LCIA and included characterization, damage assessment, normalization and single score results. The characterization step demonstrated the environmental impact of the five LCS life cycles across 15 impact categories. Throughout all categories, without exception, a general decrease in impacts can be observed in proportion to the RAP rate used.

The most important conclusions that can be drawn from this study are the following:

- The incorporation of RAP in bituminous mixtures, and especially considering its multi-recycling, had lesser environmental impacts than the use of solutions with only virgin materials.

- The most significant impact factors considered in this case study were human health, natural resources and climate change or global warming. The LCA case study demonstrated that across all factors, RAP incorporation is beneficial and significantly reduces the impact.

- Moreover, a linear correlation was established between the RAP incorporation rate and the environmental impact. This suggested that, theoretically, when constructing or maintaining flexible pavement courses, a 100\% RAP incorporation (or the complete recycling and multi-recycling of materials) should be pursued.

Although these results may seem promising, it should be considered that this case study represented certain practices, and hence it should be adapted for other construction, maintenance and rehabilitation scenarios, and for different geographic regions or types of pavements.

It should be pointed out that the data for this study was obtained from multiple active companies and experts to provide the most possible accurate and comprehensive input for the case study.

In conclusion, the case study of a road section rehabilitation has demonstrated a clear decrease in the environmental impact when RAP was reused, either once or multiple times, during M\&R phases. The multi-recycling of flexible pavement should, therefore, be favored over using virgin materials in new bituminous mixtures. Besides the study on the environmental benefits of RAP multi-recycling, significant worldwide research has been carried out to address the mechanical and durability advantages of this technology with promising results.

Bearing in mind that decision-making in pavement management is a fairly difficult approach, the LCA approach should be integrated toward a multi-purpose optimization framework and should include factors such as: social dimension, structural objectives, constraints and life cycle cost analyses. In this way, it should be performed to calculate the associated costs. Furthermore, it should be noted that the choice for the software tools to perform an LCA, as well as for the database and the impact assessment method has a distinctive influence on results. Therefore, further work should be done with a view to cross-examine the same functional unit across different tools. 
Author Contributions: Conceptualization, V.A.; methodology, V.A.; software, D.V.; validation, V.A.; formal analysis, D.V. and V.A.; investigation, D.V.; resources, J.N., A.C.F. and V.A.; writing-original draft preparation, D.V.; writing-review and editing, V.A., J.N. and A.C.F.; visualization, D.V.; supervision, J.N. and A.C.F. All authors have read and agreed to the published version of the manuscript.

Funding: This research was funded by Portuguese Foundation for Science and Technology, IP, grant number SFRH/BD/114715/2016.

Acknowledgments: The authors are grateful to the Portuguese Foundation for Science and Technology, IP, for the financial support provided through grant SFRH/BD/114715/2016 financed by the Portuguese Government budget. The authors also want to express their gratitude to Nele De Belie from the University of Ghent for providing the license for software SimaPro. The authors are grateful to the companies that provided the data.

Conflicts of Interest: The authors declare no conflict of interest.

\section{References}

1. NAPA; EAPA. The Asphalt Paving Industry—A Global Perspective, 2nd ed.; NAPA: Brussels, Belgium; EAPA: Lanham, MD, USA, 2011.

2. CEN. EN 13108-8: Bituminous Mixtures-Material Specifications-Part 8: Reclaimed Asphalt; European Committee for Standardization: Brussels, Belgium, 2005.

3. European Commission Sustainability and Circular Economy-Circular Economy. 2018. Available online: https://ec.europa.eu/growth/industry/sustainability/circular-economy_en (accessed on 17 June 2018).

4. COM 21 A Resource-Efficient Europe-Flagship Initiative under the Europe 2020 Strategy. Communication from the Commision to the European Parliament, the Council, the European Economic and Social Committee and the Committee of the Regions. 2011. Available online: https://eur-lex.europa.eu/legal-content/en/TXT/?uri= CELEX\%3A52011DC0021 (accessed on 5 April 2020).

5. FIEC; EBC; EFBWW; UIPI; Eurima; BUILD EUROPE; RICS; CEMBUREAU; GCP EUROPE; EDA; et al. CONSTRUCTION 2050-Building Tomorrow's Europe Today. 2019. Available online: http://www.fiec.eu/ en/news/news-2019/construction-2050-building-tomorrows-europe-today.aspx (accessed on 15 March 2020).

6. Santos, J.; Cerezo, V.; Flintsch, G.; Ferreira, A. Environmental and economic assessment of pavement construction and management practices for enhancing pavement sustainability. Resour. Conserv. Recycl. 2017, 116, 15-31. [CrossRef]

7. EAPA. Asphalt the 100\% Recyclable Construction Product EAPA Position Paper; EAPA: Brussels, Belgium, 2014.

8. EAPA; EUPAVE; FEHRL. Road Pavement Industries Highlight Huge CO2 Savings Offered by Maintaining and Upgrading Roads. 2016. Available online: https://eapa.org/eapa-eupave-fehrl-position-paper/ (accessed on 15 March 2020).

9. Said, F.M.; Bolong, N.; Gungat, L. Life Cycle Assessment of Asphalt Pavement Construction and Maintenance-A Review. In Proceedings of the 10th Annual Seminar on Science and Technology, Pahang, Malaysia, 1-2 December 2012.

10. Anthonissen, J.; Van den bergh, W.; Braet, J. Review and environmental impact assessment of green technologies for base courses in bituminous pavements. Environ. Impact Assess. Rev. 2016, 60, 139-147. [CrossRef]

11. Farina, A.; Zanetti, M.C.; Santagata, E.; Blengini, G.A. Life cycle assessment applied to bituminous mixtures containing recycled materials: Crumb rubber and reclaimed asphalt pavement. Resour. Conserv. Recycl. 2017, 117, 204-212. [CrossRef]

12. Butt, A.A.; Toller, S.; Birgisson, B. Life cycle assessment for the green procurement of roads: A way forward. J. Clean. Prod. 2015, 90, 163-170. [CrossRef]

13. Keijzer, E.E.; Leegwater, G.A.; de Vos-Effting, S.E.; de Wit, M.S. Carbon footprint comparison of innovative techniques in the construction and maintenance of road infrastructure in The Netherlands. Environ. Sci. Policy 2015, 54, 218-225. [CrossRef]

14. Hunt, R.G.; Franklin, W.E. LCA History L C A-How it Came About-Personal Reflections on the Origin and the Development of LCA in the USA. Int. J. Life Cycle Assess. 1996, 1, 4-7. [CrossRef]

15. Butt, A.A.; Mirzadeh, I.; Toller, S.; Birgisson, B. Life cycle assessment framework for asphalt pavements: Methods to calculate and allocate energy of binder and additives. Int. J. Pavement Eng. 2014, 15, $290-302$. [CrossRef] 
16. Jiang, R.; Wu, P. Estimation of environmental impacts of roads through life cycle assessment: A critical review and future directions. Transp. Res. Part D Transp. Environ. 2019, 77, 148-163. [CrossRef]

17. CEN. Environmental Management_Life Cycle Assessment_Principles and Framework; ISO EN 14040; European Committee for Standardization: Brussels, Belgium, 2006.

18. Steen, B.; Carlson, R.; Lyrstedt, F.; Skantze, G. Sustainability Management of Businesses through Eco-Efficiency-An EXAMPLE; CPM Report No. 2009:3; Chalmers University of Technology: Göteborg, Sweden, 2009.

19. Wolf, M.-A.; Pant, R.; Chomkhamsri, K.; Sala, S.; Pennington, D. The International Reference Life Cycle Data System (ILCD) Handbook: Towards More Sustainable Production and Consumption for a Resource-Efficient Europe; European Commision: Brussels, Belgium, 2012; ISBN 9789279216404.

20. Emami, N.; Heinonen, J.; Marteinsson, B.; Säynäjoki, A.; Junnonen, J.M.; Laine, J.; Junnila, S. A life cycle assessment of two residential buildings using two different LCA database-software combinations: Recognizing uniformities and inconsistencies. Buildings 2019, 9, 10020. [CrossRef]

21. West, R.; Rodezno, C.; Julian, G.; Prowell, B.; Frank, B.; Kriech, T. NCHRP Report 779. Field Performance of Warm Mix Technologies; Transportation Research Board: Washington, DC, USA, 2014. [CrossRef]

22. Pennington, D.W.; Margni, M.; Ammann, C.; Jolliet, O. Multimedia fate and human intake modeling: Spatial versus nonspatial insights for chemical emissions in Western Europe. Environ. Sci. Technol. 2005, 39, 1119-1128. [CrossRef]

23. IPCC. 2001: Climate Change 2001: The Scientific Basis. In Contribution of Working Group I to the Third Assessment Report of The Intergovernmental Panel on Climate Change; Houghton, J.T., Ding, Y., Griggs, D.J., Noguer, M., van der Liden, P.J., Dai, X., Maskell, K., Johnson, C.A., Eds.; Cambridge University Press: Cambrige, UK; New York, NY, USA, 2001; p. 881.

24. Araújo, J.P.C.; Oliveira, J.R.M.; Silva, H.M.R.D. The importance of the use phase on the LCA of environmentally friendly solutions for asphalt road pavements. Transp. Res. Part D Transp. Environ. 2014, 32, 97-110. [CrossRef]

25. CEN. Tests for General Properties of Aggregates-Part 1: Methods for Sampling; NP EN 932-1:20022002; British Standard Institution: London, UK, 1997.

26. Cameron, D.A.; Azam, A.H.; Rahman, M.M. Recycled clay masonry and recycled concrete aggregate blends in pavement. In Proceedings of the GeoCongress 2012: State of the Art and Practice in Geotechnical Engineering, Oakland, CA, USA, 25-29 March 2012; pp. 1532-1541. [CrossRef]

27. Rahman, M.M.; Beecham, S.; Iqbal, A.; Karim, M.R.; Rabbi, A.T.Z. Sustainability assessment of using recycled aggregates in concrete block pavements. Sustainability 2020, 12, 4314. [CrossRef]

28. Europen Commission. 614-Communication from the Commission to the European Parliament, the Council, The European Economic and Social Committee and the Committee of the Regions. In Closing the Loop-An EU Action Plan for the Circular Economy; European Commission: Brussels, Belgium, 2015.

29. Antunes, M.D.L. Circular economy: Construction with added value (in Portuguese). In Proceedings of the Seminar: CDW a Valuable Resource (in Portuguese), Lisbon, Portugal, 19 September 2016.

30. Macarthur, F.E. Circular Economy. 2011. Available online: https://www.ellenmacarthurfoundation.org/ circular-economy/infographic (accessed on 22 October 2018).

31. Zaumanis, M.; Mallick, R.B.; Frank, R. Use of Rejuvenators for Production of Sustainable High Content Rap Hot Mix Asphalt. In Proceedings of the XXVIII International Baltic Road Conference, Vilnius, Lithuania, 26-28 August 2013; pp. 1-10.

32. Zaumanis, M.; Mallick, R.B.; Frank, R. 100\% recycled hot mix asphalt: A review and analysis. Resour. Conserv. Recycl. 2014, 92, 230-245. [CrossRef]

33. Silva, H.M.R.D.; Oliveira, J.R.M.; Jesus, C.M.G. Are totally recycled hot mix asphalts a sustainable alternative for road paving? Resour. Conserv. Recycl. 2012, 60, 38-48. [CrossRef]

34. Martinho, F.C.G.; Picado-santos, L.G.; Capitão, S.D. Mechanical properties of warm-mix asphalt concrete containing different additives and recycled asphalt as constituents applied in real production conditions. Constr. Build. Mater. 2017, 131, 78-89. [CrossRef]

35. Porot, L.; Di Nolfo, M.; Polastro, E.; Tulcinsky, S. Life cycle evaluation for reusing Reclaimed Asphalt with a bio-rejuvenating agent. In Proceedings of the 6th Eurasphalt \& Eurobitume Congress, Prague, Czech Republic, 1-3 June 2016; pp. 1-8. [CrossRef]

36. McDaniel, R.; Michael Anderson, R. Recommended Use of Reclaimed Asphalt Pavement in the Superpave Mix Design Method: Technician's Manual Transportation; NCHRP REPORT 452; National Academy Press: Washington, DC, USA, 2001. 
37. Antunes, V.; Freire, A.C.; Neves, J. A review on the effect of RAP recycling on bituminous mixtures properties and the viability of multi-recycling. Constr. Build. Mater. 2019, 211, 453-469. [CrossRef]

38. Al-Qadi, I.L.; Aurangzeb, Q.; Carpenter, S.H.; Pine, W.J.; Trepanier, J. Impact of High RAP Content on Structural and Performance Properties of Asphalt Mixtures; FHWA-ICT-12-002; Illinois Center for Transportation: Rantoul, IL, USA, 2012.

39. Batouli, M.; Bienvenu, M.; Mostafavi, A. Putting sustainability theory into roadway design practice: Implementation of LCA and LCCA analysis for pavement type selection in real world decision making. Transp. Res. Part D Transp. Environ. 2017, 52, 289-302. [CrossRef]

40. Zhang, Y.; Goulias, D.; Aydilek, A. Sustainability evaluation of pavements using recycled materials. In Bearing Capacity of Roads, Railways and Airfields, Proceedings of the 10th International Conference on the Bearing Capacity of Roads, Railways and Airfields_BCRRA 2017, Athens, Greece, 28-30 June 2017; Loizos, A., Al-Qadi, I., Scarpas, T., Eds.; CRC Press-Taylor \& Francis Group: London, UK, 2017; pp. 1283-1291. [CrossRef]

41. Zaumanis, M.; Mallick, R.B.; Frank, R. 100\% Hot Mix Asphalt Recycling: Challenges and Benefits. Transp. Res. Procedia 2016, 14, 3493-3502. [CrossRef]

42. West, R.; Willis, J.R.; Marasteanu, M. Improved Mix Design, Evaluation, and Materials Management Practices for Hot Mix Asphalt with High Reclaimed Asphalt Pavement Content; NCHRP Report 752; National Academy Press: Washington, DC, USA, 2013.

43. Elkashef, M.; Williams, R.C. Improving fatigue and low temperature performance of $100 \%$ RAP mixtures using a soybean-derived rejuvenator. Constr. Build. Mater. 2017, 151, 345-352. [CrossRef]

44. Huang, B.; Zhang, Z.; Kingery, W.; Zuo, G. Fatigue crack characteristics of HMA mixtures containing RAP. In Proceedings of the Fifth International RILEM Conference on Reflective Cracking in Pavements, Limoges, France, 5-8 May 2004; pp. 631-638.

45. Nguyen, V.H. Effects of Laboratory Mixing Methods and RAP Materials on Performance of Hot Recycled Asphalt Mixtures. Ph.D. Thesis, University of Nottingham, Nottingham, UK, 2009.

46. Mogawer, W.S.; Booshehrian, A.; Vahidi, S.; Austerman, A.J. Evaluating the effect of rejuvenators on the degree of blending and performance of high RAP, RAS, and RAP/RAS mixtures. Road Mater. Pavement Des. 2013, 14, 193-213. [CrossRef]

47. Baptista, A.M.C. Hot Recycled Bituminous Mixtures in Plant-A Contribution to Its Study and application. Ph.D. Thesis, University of Coimbra, Coimbra, Portugal, 2006. (In Portuguese).

48. Al-Qadi, I.L.; Carpenter, S.H.; Roberts, G.; Ozer, H.; Aurangzeb, Q.; Elseifi, M.; Trepanier, J. Determination of Usable Residual Asphalt Binder in RAP; Research Report ICT-09-031; Illinois Center for Transportation: Rantoul, IL, USA, 2009.

49. Henely, R. Evaluation of Recycled Asphalt Concrete Pavements-Project SN-1179(6). Iowa. 1980. Available online: https://trid.trb.org/view/1124675 (accessed on 13 August 2020).

50. Hellriegel, E.J. FHWA/NJ-81/002-Bituminous Concrete Pavement Recycling; Federal Highway Administration: Washington, DC, USA, 1980.

51. Santos, L.G.d.P.; Baptista, A.M.d.C.; Capitão, S.D. Assessment of the Use of Hot-Mix Recycled Asphalt Concrete in Plant. J. Transp. Eng. ASCE 2010, 136, 1159-1164. [CrossRef]

52. Baptista, A.M.; Picado-Santos, L.G.; Capitão, S.D. Design of hot-mix recycled asphalt concrete produced in plant without preheating the reclaimed material. Int. J. Pavement Eng. 2013, 14, 95-102. [CrossRef]

53. Bloomquist, D.; Diamond, G.; Oden, M.; Ruth, B.; Tia, M. Engineering and Environmental Aspects of Recycled Materials for Highway Construction; FHWA-RD-93-088; Western Research Inst.: Laramie, WY, USA, 1993.

54. Little, D.N.; Epps, J.A. Evaluation of Certain Structural Characteristics of Recycled Pavement Materials. In Proceedings of the Association of Asphalt Paving Technologists Proceedings, Louisville, KY, USA, 18-20 February 1980.

55. Sullivan, J. FHWA-SA-95-060. Pavement Recycling Executive Summary and Report; Federal Highway Administration: Washington, DC, USA, 1996.

56. Zaumanis, M.; Mallick, R.B.; Frank, R. Evaluation of Rejuvenator's Effectiveness with Conventional Mix Testing for 100\% RAP Mixtures. In Proceedings of the Transportation Research Board 92nd Annual Meeting, Washington, DC, USA, 13-17 January 2013; pp. 17-25.

57. Pereira, P.A.A.; Oliveira, J.R.M.; Picado-Santos, L.G. Mechanical characterisation of hot mix recycled materials. Int. J. Pavement Eng. 2004, 5, 211-220. [CrossRef] 
58. Valdés, G.; Pérez-Jiménez, F.; Miró, R.; Martínez, A.; Botella, R. Experimental study of recycled asphalt mixtures with high percentages of reclaimed asphalt pavement (RAP). Constr. Build. Mater. 2011, 25, 1289-1297. [CrossRef]

59. Shu, X.; Huang, B.; Vukosavljevic, D. Laboratory evaluation of fatigue characteristics of recycled asphalt mixture. Constr. Build. Mater. 2008, 22, 1323-1330. [CrossRef]

60. Daniel, J.S.; Lachance, A. Mechanistic and volumetric properties of asphalt mixtures with recycled asphalt pavement. Bitum. Paving Mix. 2005 2005, 28-36. [CrossRef]

61. Botella, R.; Pérez-Jiménez, F.; Miró, R.; Guisado-Mateo, F.; Ramírez Rodríguez, A. Characterization of Half-Warm-Mix Asphalt with High Rates of Reclaimed Asphalt Pavement. Transp. Res. Rec. J. Transp. Res. Board 2016, 2575, 168-174. [CrossRef]

62. Farooq, M.A.; Mir, M.S.; Sharma, A. Laboratory study on use of RAP in WMA pavements using rejuvenator. Constr. Build. Mater. 2018, 168, 61-72. [CrossRef]

63. Wang, Y. The effects of using reclaimed asphalt pavements (RAP) on the long-term performance of asphalt concrete overlays. Constr. Build. Mater. 2016, 120, 335-348. [CrossRef]

64. Stroup-Gardiner, M. Use of Reclaimed Asphalt Pavement and Recycled Asphalt Shingles in Asphalt Mixtures; Transportation Research Board: Washington, DC, USA, 2016.

65. Gong, H.; Huang, B.; Shu, X. Field performance evaluation of asphalt mixtures containing high percentage of RAP using LTPP data. Constr. Build. Mater. 2018, 176, 118-128. [CrossRef]

66. Ecoinvent System Models in Ecoinvent 3. 2019. Available online: https://www.ecoinvent.org/database/ system-models-in-ecoinvent-3/system-models-in-ecoinvent-3.html (accessed on 6 September 2019).

67. Santos, J.; Bressi, S.; Cerezo, V.; Lo Presti, D.; Dauvergne, M. Life cycle assessment of low temperature asphalt mixtures for road pavement surfaces: A comparative analysis. Resour. Conserv. Recycl. 2018, 138, $283-297$. [CrossRef]

68. Rodriguez-Alloza, A.M.; Malik, A.; Lenzen, M.; Gallego, J. Hybrid input-output life cycle assessment of warm mix asphalt mixtures. J. Clean. Prod. 2015, 90, 171-182. [CrossRef]

69. Bressi, S.; D’Angelo, G.; Santos, J.; Giunta, M. Environmental performance analysis of bitumen stabilized ballast for railway track-bed using life-cycle assessment. Constr. Build. Mater. 2018, 188, 1050-1064. [CrossRef]

70. Walls-III, J.; Smith, M.R. Life-Cycle Cost Analysis in Pavement Design-Interim Technical Bulletin; FHWA-SA-98-079; Federal Highway Administration: Washington, DC, USA, 1998.

71. Babashamsi, P.; Md Yusoff, N.I.; Ceylan, H.; Md Nor, N.G.; Salarzadeh Jenatabadi, H. Evaluation of pavement life cycle cost analysis: Review and analysis. Int. J. Pavement Res. Technol. 2016, 9, 241-254. [CrossRef]

72. Thiessen, P.; Collins, J.; Buckland, T.; Abbell, R. Valuing the wider benefits of road maintenance funding. Transp. Res. Procedia 2017, 26, 156-165. [CrossRef]

73. Dinis-Almeida, M.; Castro-Gomes, J.; Antunes, M.L. Mechanical Performance and Economic Evaluation of Warm Mix Recycling Asphalt. Procedia Soc. Behav. Sci. 2012, 53, 286-296. [CrossRef]

74. JRC-IES. International Reference Life Cycle Data System (ILCD) Handbook-General Guide for Life Cycle Assessment_Detailed Guidance; European Commission-Joint Research Centre-Institute for Environment and Sustainabilitty: Luxemborg, 2010.

75. Pré Consultants. SimaPro Database Manual Methods Library. 2019. Available online: http://creativecommons. org/licenses/by-nc-sa/3.0/nl/deed.en_US (accessed on 15 February 2019).

76. Pré Consultants. SimaPro 7-Database Manual-EU \& DK Input Output Database. 2010. Available online: https://www.pre-sustainability.com/legacy/download/manuals/DatabaseManualEUDKIODatabase.pdf (accessed on 15 February 2019).

77. CEN. Bituminous Mixtures. Test Methods for Hot Mix Asphalt_Part 35: Laboratory Mixing; EN 12697-35; European Committee for Standardization: Brussels, Belgium, 2004.

78. Santero, N.J.; Masanet, E.; Horvath, A. Life-cycle assessment of pavements. Part I: Critical review. Resour. Conserv. Recycl. 2011, 55, 801-809. [CrossRef]

79. GocEkoop, M.; Spriemsma, R. The Eco-Indicator 99 A Damage Oriented Method for Life Cycle Impact Assessment, 3rd ed.; PRé Consultants B.V.: Amersfoort, The Netherlands, 2001.

80. Guinée, J. Handbook on Life Cycle Assessment: Operational Guide to the ISO Standards (Eco-Efficiency in Industry and Science); Kluwer Academic Publishers: Dordrecht, The Netherlands, 2002; ISBN 978-1402005572. 
81. Humbert, S.; De Schryver, A.; Margni, M.; Jolliet, O. IMPACT 2002+: User Guide. 2012. Available online: http://onlinelibrary.wiley.com/o/cochrane/clcentral/articles/506/CN-00756506/frame.html (accessed on 20 February 2019).

82. Bressi, S.; Santos, J.; Giunta, M.; Pistonesi, L.; Lo Presti, D. A comparative life-cycle assessment of asphalt mixtures for railway sub-ballast containing alternative materials. Resour. Conserv. Recycl. 2018, 137, 76-88. [CrossRef]

83. Santos, J.; Ferreira, A.; Flintsch, G. A life cycle assessment model for pavement management: Methodology and computational framework. Int. J. Pavement Eng. 2015, 16, 268-286. [CrossRef]

84. Santos, J. A Comprehensive Life Cycle Approach for Managing Pavement Systems. Ph.D. Thesis, University of Coimbra, Coimbra, Portugal, 2015.

(C) 2020 by the authors. Licensee MDPI, Basel, Switzerland. This article is an open access article distributed under the terms and conditions of the Creative Commons Attribution (CC BY) license (http://creativecommons.org/licenses/by/4.0/). 